\title{
Psycho-oncological intervention in haematopoietic progenitor cell transplant (HPT): Effects of emotional impact
}

\section{Intervención psicooncológica en Trasplante de Progenitores Hematopoyéticos (TPH): Efectos en el impacto emocional.}

\author{
Soledad de Linares-Fernández \\ Hematology Service of the University Hospital Virgen de las Nieves \\ soledad.linares.exts@juntadeandalucia.es \\ $M^{a}$ Nieves Pérez-Marfil \\ Department of Personality, Evaluation and Psychological Treatment \\ University of Granada \\ nperez@ugr.es \\ Francisco Cruz-Quintana \\ Department of Personality, Evaluation and Psychological Treatment \\ University of Granada \\ fcruz@ugr.es \\ Antonio Romero-Aguilar \\ Hematology Service of the University Hospital Virgen de las Nieves \\ antonio.romero.aguilar.ssps@juntadeandalucia.es \\ Lucía Moratalla-López \\ Hematology Service of the University Hospital Virgen de las Nieves \\ luciamolo77@hotmail.com \\ Elisa López-Fernández \\ Hematology Service of the University Hospital Virgen de las Nieves \\ eliku77@hotmail.com
}




\title{
Resumen
}

El objetivo de este trabajo ha sido determinar las repercusión un programa de intervención psicooncológica sobre los pacientes candidatos a un Trasplante de Progenitores Hematopoyéticos (TPH). Participan dos grupos de pacientes, el grupo intervención $(n=21)$, formado por los pacientes que han realizado el programa de intervención previo al trasplante, y un grupo de control $(n=15)$, que no recibe la intervención pre-TPH. El programa consta de cuatro módulos: análisis y manejo de la información, habilidades de afrontamiento, control del estrés, y preparación familiar al aislamiento. Los resultados muestran que los pacientes que reciben la intervención psicológica obtienen niveles menores en ansiedad y depresión y tiene una percepción más adaptativa del paso del tiempo y un estado de ánimo más positivo, con más actividad que el grupo de control. Sin embargo, tales diferencias no son significativas en la percepción de la sintomatología física que aumenta con el paso del tiempo en aislamiento.

Palabras clave: TPH; Intervención Psicooncológica; Ansiedad; Depresión; Percepción Tiempo.

\begin{abstract}
The aim of this work has been to determine the repercussions a psycho-oncological program has on patients who need to undergo a haematopoietic stem cell transplantation (HPT). We have studied two groups, an intervention group $(\mathrm{n}=21)$, formed with patients that have gone through the program of psycho-oncologic preparation previous to the transplant, and a control group $(n=15)$, without psychological intervention. The program consists of four sessions: analysis and handling of the information, coping skills, management of stress, and preparation for the isolation. The results show that patients who receive the psychological intervention. appear to obtain minor levels in anxiety and depression and has a more adaptive perception of the passage of time and a more positive mood with more activity than the control group. However, such differences are not significant in the perception of the physical symptomatology as the amount of time in isolation increases.
\end{abstract}

Key words: HPT; Psycho-oncological Intervention; Anxiety; Depression; Time Perception. 
Bone marrow transplant is a therapeutic option in the treatment of multiple illnesses due to either primary alterations in bone marrow, or the administration of high doses of chemotherapy and/or radiotherapy in different oncho-haematologic processes. We can distinguish various types of transplants depending on the donor (Carreras et al., 2006). If they are a sibling with identical HLA (human leukocyte antigen): allogeneic transplant; if they are a sibling or another relative with non-identical HLA: haploidentical transplant; if they are not related to the patient: unrelated donor transplantation; or if the donor is the patient: autologous transplant. We can also distinguish the type of transplant depending on the origin of the stem cells: if the cells originate directly from the marrow, it is known as bone marrow transplant (BMT); if they come from the blood, it is known as peripheral blood progenitor cell transplantation (HPT); and if they come from the blood of the umbilical cord of a newborn baby, it is known as umbilical cord transplant (Ruiz, 2009).

The transplant of haematopoietic progenitor cells (HPT) is a relatively new treatment that significantly increases the survival rate in patients with haematological diseases such as leukaemia, lymphoma, and myeloma. In such treatment, after the extraction of peripheral blood stem cells through apheresis, from the patient or from the donor, we administer a high dose of chemotherapy, or radiotherapy in some cases, which eliminates every pathological cell from the organism and/or destroys the unhealthy marrow to substitute it for healthy marrow (Sans-Sabrafen, Berres, \& Vives, 2006).

Despite advances in the treatment, the patients have to accept the risks of suffering and death. The secondary effects of chemotherapy treatment and/or radiotherapy (nausea, vomiting, pain, mucositis, alopecia, etc), combined with the long period in isolation, and the separation from the relatives, tend to influence the mood (Gabriel et al., 2001; Mosher, Redd, Rini, Burkhalter, \& DuHamel, 2009; Wettergren, Sprangers, Björkholm, \& Langins-Eklöf, 2008; Watson , James-Roberts \& Ashley, 2006; Wettergren, Sprangers, Björkholm, \& Langins-Eklöf, 2008)., , 5, 6,7,8). In spite of this, patients who receive a transplant tend to value this treatment positively, because it involves a technical contribution to the fight against the illness and involves useful research (Hengeveld, Houtman, \& Zwan, 19889).

We have been working for a long time with the idea that the psychological problems these patients may present are comparable to situations of social isolation, parent-child separation or sensory deprivation (Lesko, Kern \& Hawkins,
1984) $\left({ }^{10}\right)$. One of the pioneering studies in relating the situation of isolation to psychological variables was that of Holland et al. (1977)( $\left({ }^{11}\right)$. It concludes that, in general, patients adapt to the protected environment and maintain emotional stability, with their psychological functioning closely linked to their physical state. Many patients tend to tolerate the situation of isolation, though there are causative factors of stress associated with the same one that can be relieved. Anxiety is the reaction that appears more often previous to the transplant. Nevertheless, during convalescence either anxiety or depression can appear, increasing the latter if difficulties in the transplant arise and the hospitalization in being prolonged (Asensio, 2011; Trask, Paterson, Riba, Brine, Griffi \& Parker, 2002): $\left({ }^{12,13}\right)$.

Taking everything all these things into account transplant could be considered a stressful process that requires from the patients to develop confrontation strategies. These consist of cognitive and behavioral efforts that help them to adapt to the internal and external demands, in which the aptitude to analyze new situations and create new mechanisms of confrontation importance (Schroevers, Kraaij \& Garnefski, 2011). (14).

Psychological time is a fundamental element in the adaptation of the organism to its environment, since a deficit in the estimation of time can produce an imbalance in daily life situations and can degrade the quality of life (Gambara, Botella \& Gempp, 2002) ${ }^{(16)}$. In 1890, James differentiated between objective and subjective time, suggesting that the same space of time seems shorter as we grow older, although, it concludes that whereas this happens with days, months, and years, it is more difficult for the same to happen with hours.

Campion $(2001)^{(16)}$ declared that the evaluation of objective time is determined by objective, clear and consistent measures (watches, calendars, etc.), whereas subjective time is determined by feelings. In Bayés (2000a) ${ }^{(17)}$ words, chronometric time, the objective, is the time of watches, that allows organisation of our society and our life, but the time that is really important for us is subjective time. The duration of time is perceived according to our own personal biography and the expectations and events we are exposed to (Bayés, 2000b) ${ }^{(18)}$.

If the disruption in the estimation of time can degrade the quality of people's lives, it is not illogical to think about the importance that this parameter takes in those people with health problems. Bayés, et al. (2001a) ${ }^{(19)}$ analysed the relation in 371 patients in a terminal situation. They observed that whereas $83.5 \%$ of the patients who said that the passage 
of time was "long" or "very long", they declared that they felt "average", "bad" or "very bad"; $76.6 \%$ of those who said that the passage of time was "short" or "too short" declared that they felt "good" or "very good". In general, this author proposes that somatic symptoms, aversion to physical environmental stimuli, depressive states of mood or anguish, and the waiting time are variables that influence the lengthening of time. He asserts that the lengthening of patients' perception of time is associated with a susceptible disagreeable situation, spanning from simple boredom to an intense suffering. Where the perception of time is shortened, the likely reason ranges from participation in cognoscitive activities that require a high level of attention to those activities that bring moments of intense happiness. Also, Bayés (2001b) ${ }^{(20)}$ asserts that with just a simple question about time perception, one can know the state of wellness or illness of many hospitalised patients.

A peculiarity to take into account in medical care relationships is that the subjective perception of time varies between patients and health workers. This difference may lead to increasing suffering in patients and their relatives, due to this temporal perceptive phase lag, which may go unnoticed by health workers when carrying out their duties, or may be ignored by them, owing to a belief that it is beyond their capabilities and/or responsibilities (Bayés, Limonero, Barreto \& Comas, 2001) $)^{(21}$.

On the other hand, there are many studies that associate the perception of the passage of time with several variables. One of the variables that influences the perception of the passage of time is directly related to age, in such a way that if age increases, the "internal clock's" rhythm slows down; it is the biological pace-maker that fixes the rhythm of activities in general, and in particular the rhythm of cognitive tasks. Within this context, they have proposed attention deficits associated with age and related to an inhibitory deficit (Schroots \&, Birren, 1990) ${ }^{(22)}$ with the speed of processing (Salthouse, 1991) ${ }^{23)}$, or with the reduction of the functional visual field (Ball, Beard, Roenker, Miller \& Griggs, 1988) ${ }^{(24)}$. Thus, Juola $(2001)^{(25)}$ proposes the general hypothesis that with increasing age the processing attention resources are reduced.

Fraisse (1984) ${ }^{(26)}$ affirmed that "the more attention we pay to time passing, the longer this seems, being the maximum lengthening when one is only awaiting for a desired or feared event to happen. Conversely, the duration seems to reduce when the task being carried out is difficult and/or interesting". When a person is completely absorbed by the task being carried out, time seems to shorten and hours pass almost without being perceived.
In healthcare it is generally considered that the patient perceives the duration of time as longer than the one marked by the clock in three cases (Bayés, Limonero, Barreto \& Comas, 1997; Bayés, 2003) $)^{(27,28)}$ : a) when the situation or state he is in produces discomfort due to environmental physical factors (noise, heat, cold, smoke, bad smells, etc), psychosocial factors (visitors or irritating roommates, boredom), somatic symptoms (pain, dyspnea) or negative thoughts (feelings of fear, loneliness, guilt, abandonment, loss); b) when his mood is anxious or depressive; c) during the waiting periods. With respect to the mood, Watson et al. $(1995)^{(29)}$ state that depression and hopelessness, apart from having negative effects on the course of illness, contribute to dilate the perception of time passing.

As previously mentioned, the transplant is considered a stressful process that requires the patient to put in place a series of coping strategie. That is, cognitive and behavioural efforts that help them to adapt to internal and external demands, thus making the ability to analyse new situations and to create new coping mechanisms important. Lesko (1989) ${ }^{(30)}$ states that the ability to delegate control to others and to establish close relationships with the team are important for the patient's adaptation to the state of isolation. Likewise, Neuser $(1988)^{(31)}$ proved that patients who collaborate in the treatment actively ask others for help. They try to obtain the recognition of people, and they adapt better than those who do not carry out these strategies.

The main purpose of any psychological intervention in patients diagnosed with cancer is to aid toleration of the diagnosis and treatment, decreasing the feelings of defencelessness and abandonment, reducing the anxiety related to the treatments, and clarifying any erroneous information and perceptions (Dempster, McCorry, Brennan, Donnelly, Murray \& Johnston, 2011; Dobkin \& Costa, 2000; Hou, Law \& Fu, 2010; Novoa, Vargas, Obispo, Petrus \& Rivera, 2010; Pinquart \& Fröhlich, 2009) ${ }^{32,33,34,35,36)}$. According to Bárez, et al. $(2003)^{37)}$, the strategies that are carried out in this type of situation are related to emotional support, in terms of the patient feeling that they are being listened to, understood, encouraged and well cared for, to educational-informational support, which favours the necessary level of information to be able to handle the whole process, and to instrumental support, where the patients are provided with different economic and material resources or with home assistance.

Folkman \& Creer (2000) ${ }^{(38)}$, state that every therapeutic program for seriously ill patients should encourage wellbeing, considering as objectives: a) creating an opportunity for a "challenge", finding out what is important for the patient, establishing targets and highlighting the opportunities for 
personal control; b) promoting the achievement of these targets; c) and maintaining a positive mood by recalling positive events with the patient.

The cognitive and behavioural programs called Adjuvant Psychological Therapy (APT) are characterised by being structured, brief (6-12 sessions), and focused on the problem. They use tasks that are performed at home, as well as a variety of treatment techniques: behavioural techniques (relaxation, graduated tasks, and the planning of activities); cognitive techniques (register of automatic thoughts, coping cognitive strategies, and cognitive restructuring); as well as non-directive methods such as ventilation of feelings. The efficiency of this type of psychological intervention in healthcare has been proved through different studies (De Linares et al., 2007; Cruzado \& Olivares, 2000) ${ }^{(39,40)}$. The results reflect an improvement in levels of anxiety, depression and adoption of positive coping strategies. Subsequently, this type of intervention has been adapted with success to oncohaematologic patients.

At the Haematology Department at the University Hospital in Granada (Spain), a psychological intervention program is being carried out for people who have to undergo a haematopoietic progenitor cell transplant. The objectives of this pilot research have been to determine the emotional impact on patients who have to undergo a haematopoietic progenitor cell transplant (HPT) and the repercussions of a psycho-oncologic program in preparation for the transplant, on time perception, mood, and perception of physical symptomatology.

\section{METHOD}

\section{Design}

It is a pilot study in which a quasi-experimental design was used with two groups, an intervention group and a control group, in which the changes that took place between periods before and after the transplant were analysed. A deliberate sampling was made taking into account the characteristics of the patients. Access to the candidate patients for HPT is limited for logistical and ethical restrictions; this is the reason for a non-random sampling (Kirchhoff \& Kehl, 2007) ${ }^{(41) .}$

\section{Participants}

The patients in this research are candidates for HPT, 15 men and 21 women $(n=36)$, divided into two main groups: a) Intervention Group $(\mathrm{n}=21)$ formed by patients diagnosed with that pathology at the Haematology Department at the
University Hospital Virgen de Las Nieves, and who receive treatment previous to HPT, either at the hospital ward or at the day hospital. This group undergoes the psycho-oncologic program from the moment they are admitted in protocol for HPT; b) Control group ( $\mathrm{n}=15)$, formed by patients who are diverted to the Haematology Department to undergo the transplant. This group does not receive the psycho-oncologic program because of hospital admission procedures.

This unit has a capacity to carry out between 25 and 30 transplants per year. Our research was made during two years and we completed 54 interviews to all patients that went through the unit. Of these patients, 38 signed the consent form to participate in this research (23 in the intervention group and 15 in the control group), 14 did not receive the transplant in the end ( 10 due to changes in their treatment, and 4 due to death before the HPT), and 2 decided not to take part in the research. During the isolation period, data was collected on the day of the transplant (Day 0) of all samples (38 patients), whereas the collection of data on the day of discharge (around Day 25) came from 36 patients. This is due to the fact that two of them passed away during the isolation period.

The allocation to the groups was determined by whether it was possible for the patient to undergo the psycho-oncological intervention or not. This means that those patients who were admitted to hospital for a treatment (chemotherapy and/ or apheresis) previous to the transplant became part of the intervention group after giving their consent. On the contrary, those patients who were admitted into hospital directly to receive the transplant, without a previous stay in hospital, became part of the control group.

The average age of the patients that participate in this study is 43.57 years $(\mathrm{SD}=13.11)$. The diagnoses are the following ones: leukaemia $(n=12)$, lymphoma $(n=17)$, myeloma $(n=5)$ and another $(n=2) .27$ patients received an autologous transplant and 9 an allogeneic transplant.

\section{Measurements}

- Hospital Anxiety and Depression Scale (HADS) (Zigmond \& Snaith, 1983) ${ }^{(42)}$. It's commonly used to determine the levels of anxiety and depression that a patient is experiencing. The HADS is a fourteen item scale and each item on the questionnaire is scored from 0-3 and this means that a person can score between 0 and 21 for either anxiety or depression. For anxiety (HADS-A) this gave a specificity of .78 and a sensitivity of .90. For depression (HADS-D) this gave a specificity of .79 and a sensitivity of .83 (Bjelland, Dahl, Haugh, \& Neckelmann, 2002). 


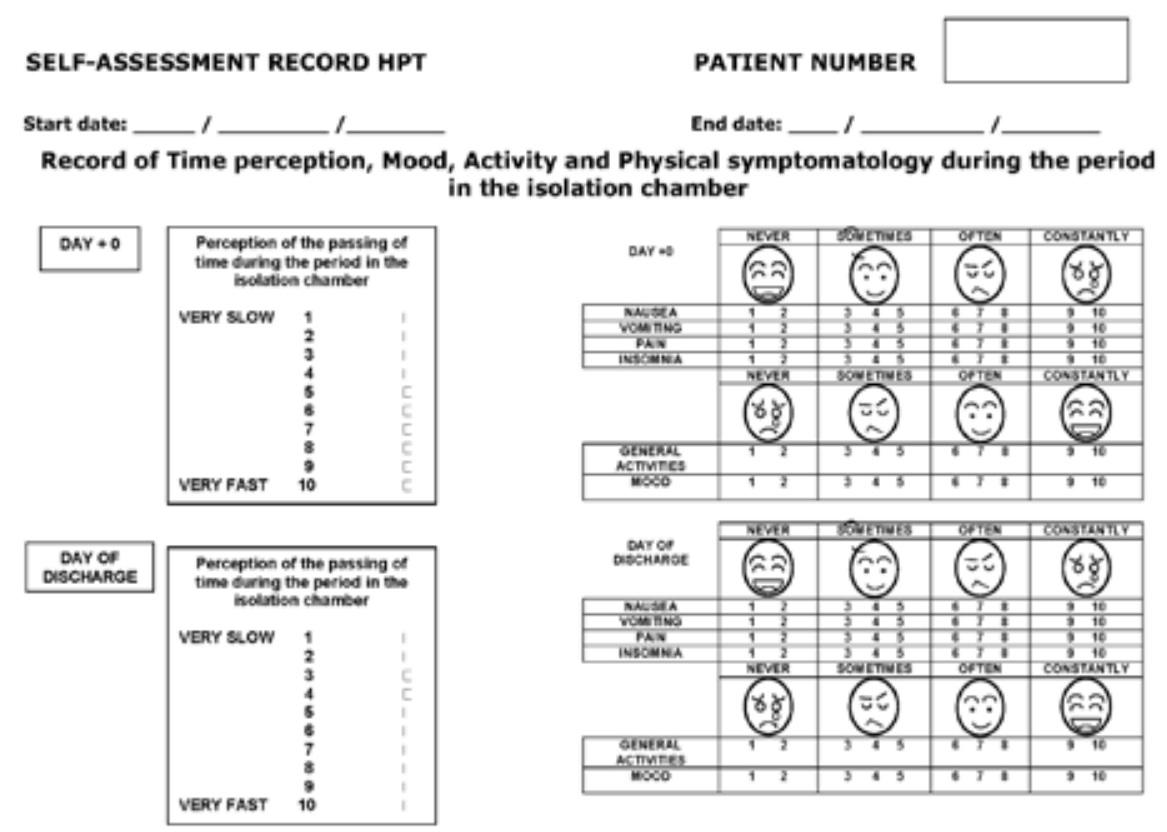

Figure 1 Self-Assessment Record

- Self-assessment record HPT. Based on the ideas of Bayés (21), according to which we can know the wellness or illness of many hospitalised patients by simply asking them a question about time perception, We opted for asking the patients, using a scale between 0 and 10 , about their perception of the lengthening or shortening of time, emotional state, level of activity, and physical symptoms (nausea, vomiting, pain and insomnia). This allowed the patients to be monitored continuously, within the chamber on the day of the haematopoietic progenitor cell infusion (Day +0$)$, and the day when the patient is discharged (See Figure 1).

\section{Program}

The psycho-oncological intervention program carried out at the University Hospital Virgen de Las Nieves has the objective, such as that by Arranz \& Coca $(2003)^{(44)}$, to favour the adaptation to the process of the transplant, softening the psychological impact and the associated suffering, identifying and anticipating needs, worries, and difficulties, reducing, whenever possible, the negative effects associated with the process. The strategies are based on cognitive-behavioral therapy. The phases of this program adapted to each patient according to their needs and demands are:

a. Analysis and manipulation of information: where doubts, worries and fears related to the medical information are identified and rectified, encouraging open communication with healthcare workers. In this phase, there is a first contact with the isolation chamber through a visit.

b. Coping abilities: In this phase, the coping style of a patient on encountering stressful situations is identified and is related to the whole process of the transplant, reinforcing positive attitudes and encouraging new coping strategies. At this time a list of material resources important for the patient is created (books, music, etc.) to help during their stay in isolation, which will be brought by the patient on admission to the transplant unit.

c. Managing stress: the patient is informed about the mechanisms of stress, identifying sources of stress as well as irrational thoughts that may increase it, generating alternatives to these thoughts. At the same time, there is some relaxation training through diaphragmatic breathing exercises.

d. Preparation for the transplant at family level: the level of knowledge about the procedure of the family is ascertained as well as their communicative style, thus encouraging assertiveness of the family with the patient and vice-versa. Possible stress situations are standardised and communication with all healthcare workers is facilitated. 
The sociodemographic variables (age, gender, civil status, family situation, education, employment situation) and clinical variables (diagnosis, stage, treatments, type of HPT) are obtained through a consultation of the medical history, and they are collected in a database created for the research.

\section{Procedure}

The recruitment of patients for the study is carried out at a clinical session during which the medical team decides on the need for the transplant, whether it has just been diagnosed and/or the patient is already on treatment at the unit (intervention group), or whether the transplant is requested by other services or hospitals (control group).

The first contact with the patients is made at the "welcoming to HPT session", in which the patient is informed about certain fundamental aspects related to the treatment of the transplant. It is at this time that the patient is told of the study, the informed consent form is signed, the sociodemographic data is collected, diagnosis, etc. The psycho-oncologic intervention, adapted to the treatment process, is carried out with the intervention group when the patients are in medical treatment previous to HPT, either on the ward or at the day hospital.

The psycho-oncological intervention program in preparation for HPT consists of 4 to 6 sessions that vary according to the demands of the patient, of an approximate duration of ninety minutes. They are each carried out individually, although if the patient wishes there may be a relative present, except for the family session when the family is required. The sessions are carried out by the psycho-oncologic unit in charge of the development and monitoring of the patients during the whole transplant procedure. The sessions were carried out individually in the patient's room and the interval between sessions was 24 hours. Once they were admitted onto the transplant unit, the intervention group was visited by the psycho-oncologist every two days. These sessions lasted for 30 minutes. The aim of these visits was to follow-up the strategies learnt during the intervention. The patients in the control group were offered the opportunity to demand the presence of a psycho-oncologist when they saw it appropriate, which happened exceptionally.

\section{Data analysis}

Descriptive analysis has been carried out and the differences between the groups have been examined through the statistics programme SPSS 16.0, making a comparison between groups through a general linear model for repeated measurements.

\section{RESULTS}

Below, the results of the analysis of the registered measurements during the patient's period in isolation of the sample object of study are presented.

- HADS-Anxiety: The statistical analysis (see Table 1) shows a significant reduction in anxiety levels between day 0 and the day of discharge $(F=24.909, p=.000)$; there are significant differences between the intervention and control groups, patients who receive the intervention present lower levels of anxiety than those patients in the control group $(F$ $=46.438, p=.000$ ). For both groups there is a significant reduction in anxiety.

- HADS-Depression: In the Table 1 we can see a significant reduction in depression levels $(F=6.489, p=.000)$. There are significant differences between the groups, patients who receive the intervention present lower levels of depression that those patients in the control group $(F=23.141, p=.000)$. - Perception of the passage of time: The statistical analysis (see Table 2) shows that, despite the fact that as the time spent in the isolation chamber increases, the perception of

Table 1 Statistical analysis of anxiety and, depression (means, standard deviation, size effect, F and Wilk's Lambda effect)

\begin{tabular}{|r|r|r|r|r|r|r|r|}
\hline Variable & Group & $\boldsymbol{M}(\boldsymbol{S D})$ & $\boldsymbol{M}(\boldsymbol{S D})$ & $\boldsymbol{E S}$ & Factor & $\boldsymbol{F}$ & $\boldsymbol{p}$ \\
& & Pre & Post & & & & \\
\hline HADS-Anxiety & Intervention & $5.80(2.91)$ & $4.27(2.66)$ & 0.55 & Time & 24.909 & $.000^{*}$ \\
& Control & $13.15(3.58)$ & $9.46(1.71)$ & 1.39 & Time * Group & 4.252 & $.049^{*}$ \\
& & & & Group & 46.438 & $.000^{*}$ \\
\hline HADS-Depression & Intervention & $3.67(2.41)$ & $2.53(2.45)$ & 0.47 & Time & 6.489 & $.017^{*}$ \\
& Control & $9.00(3.65)$ & $7.08(3.95)$ & 0.51 & Time * Group & 0.433 & .516 \\
& & & & & Group & 23.141 & $.000^{*}$ \\
\hline
\end{tabular}

$* p<.05$ 
time passing worsens in patients $(F=32.567, p=.000)$; there are significant differences between the intervention and control groups $(F=45.531, p=.000)$. Patients who receive the intervention present a more adaptive perception of time passing than those patients in the control group. For both groups there is a significant reduction between day 0 and the day of discharge $(F=5.211, p=.029)$.

- Perception of activity: Patients who receive the intervention perceive a greater activity during their stay in isolation than the patients in the control group $(F=54.350, p=.000)$. The statistical analysis (see Table 2 ) shows that, despite the fact that as the time spent in isolation increases $(F=68.214, p$ $=.000)$, the level of activity in all patients worsens $(F=$ $1.328, p=.257$ ).
- Perception of mood: Patients who receive the intervention present a more positive mood than those of the control group. The statistical analysis (see Table 2) shows that, despite the fact that as the time spent in the isolation chamber increases, the perception of mood worsens in patients $(F=53.904$, $p=.000)$; there are significant differences between the intervention and the control groups $(F=49.128, p=.001)$. For both groups there is a significant decrease between day 0 and the day of discharge.

- Perception of physical symptomatology: The statistical analysis (see Table 2) of the perception of physical symptomatology shows that, despite the fact that as the time spent in the isolation chamber increases, the perception of nausea $(F=5.645, p=.023)$, vomiting $(F=4.449, p=$

Table 2 Statistical analysis of time perception, perception of activity, mood and perception of physical symptomatology (means, standard deviation, size effect, F and Wilk's Lambda effect)

\begin{tabular}{|c|c|c|c|c|c|c|c|}
\hline Variable & Group & $\begin{array}{l}M(S D) \\
\text { Pre } \\
\end{array}$ & \begin{tabular}{|l}
$M(S D)$ \\
Post \\
\end{tabular} & ES & Factor & $F$ & $\bar{P}$ \\
\hline Time perception & \begin{tabular}{|l|} 
Intervention \\
Control
\end{tabular} & $\begin{array}{l}7.24(1.30) \\
4.73(1.91)\end{array}$ & $\begin{array}{l}6.38(1.83) \\
2.73(1.03)\end{array}$ & $\begin{array}{l}0.54 \\
1.29\end{array}$ & $\begin{array}{l}\text { Time } \\
\text { Time * } \\
\text { Group } \\
\text { Group }\end{array}$ & $\begin{array}{l}32.567 \\
5.211 \\
45.531\end{array}$ & $\begin{array}{l}.000^{*} \\
.029 * \\
.000^{*}\end{array}$ \\
\hline Perception of activity & $\begin{array}{l}\text { Intervention } \\
\text { Control }\end{array}$ & $\begin{array}{l}8.14(1.56) \\
4.73(1.75)\end{array}$ & $\begin{array}{l}6.38(1.94) \\
2.40(1.19)\end{array}$ & $\begin{array}{l}1.00 \\
1.55\end{array}$ & $\begin{array}{l}\text { Time } \\
\text { Time * } \\
\text { Group } \\
\text { Group }\end{array}$ & $\begin{array}{l}68.214 \\
1.328 \\
54.350\end{array}$ & $\begin{array}{l}.000^{*} \\
.257 \\
.000^{*} \\
\end{array}$ \\
\hline Mood & $\begin{array}{l}\text { Intervention } \\
\text { Control }\end{array}$ & $\begin{array}{l}8.33(1.77) \\
6.40(1.64)\end{array}$ & $\begin{array}{l}7.38(2.20) \\
2.73(0.96)\end{array}$ & $\begin{array}{l}1.32 \\
2.09\end{array}$ & $\begin{array}{l}\text { Time } \\
\text { Time * } \\
\text { Group } \\
\text { Group }\end{array}$ & $\begin{array}{l}53.904 \\
12.095 \\
49.128\end{array}$ & $\begin{array}{l}.000 * \\
.001 * \\
.000^{*}\end{array}$ \\
\hline Nausea & $\begin{array}{l}\text { Intervention } \\
\text { Control }\end{array}$ & $\begin{array}{l}3.95(1.83) \\
5.33(1.84)\end{array}$ & $\begin{array}{l}4.90(1.45) \\
6.20(1.70)\end{array}$ & $\begin{array}{l}-0.57 \\
-0.47\end{array}$ & $\begin{array}{l}\text { Time } \\
\text { Time * } \\
\text { Group } \\
\text { Group }\end{array}$ & $\begin{array}{l}5.635 \\
0.013 \\
9.760\end{array}$ & $\begin{array}{l}.023 * \\
.912 \\
.004^{*}\end{array}$ \\
\hline Vomiting & $\begin{array}{l}\text { Intervention } \\
\text { Control }\end{array}$ & $\begin{array}{l}3.76(1.76) \\
4.40(2.13)\end{array}$ & $\begin{array}{l}4.33(1.80) \\
5.40(1.72)\end{array}$ & $\begin{array}{l}-4.78 \\
-6.20\end{array}$ & $\begin{array}{l}\text { Time } \\
\text { Time * } \\
\text { Group } \\
\text { Group }\end{array}$ & $\begin{array}{l}4.449 \\
0.331 \\
2.899\end{array}$ & $\begin{array}{l}.042 * \\
.569 \\
.098\end{array}$ \\
\hline Pain & $\begin{array}{l}\text { Intervention } \\
\text { Control }\end{array}$ & $\begin{array}{l}2.71(1.95) \\
3.40(1.68)\end{array}$ & $\begin{array}{l}3.57(2.06) \\
5.73(2.22)\end{array}$ & $\begin{array}{l}-0.44 \\
-1.19\end{array}$ & $\begin{array}{l}\text { Time } \\
\text { Time * } \\
\text { Group } \\
\text { Group }\end{array}$ & $\begin{array}{l}9.676 \\
4.212 \\
6.249\end{array}$ & $\begin{array}{l}.000^{*} \\
.048^{*} \\
.017^{*}\end{array}$ \\
\hline Insomnia & $\begin{array}{l}\text { Intervention } \\
\text { Control }\end{array}$ & $\begin{array}{l}3.00(1.95) \\
5.20(1.90)\end{array}$ & $\begin{array}{l}4.14(2.20) \\
7.13(2.33)\end{array}$ & $\begin{array}{l}-0.56 \\
-0.92\end{array}$ & $\begin{array}{l}\text { Time } \\
\text { Time * } \\
\text { Group } \\
\text { Group }\end{array}$ & $\begin{array}{l}17.431 \\
1.151 \\
18.387\end{array}$ & $\begin{array}{l}.000 * \\
.291 \\
.000 *\end{array}$ \\
\hline
\end{tabular}

$* p<.05$ 
$.042)$, pain $(F=9.676, p=.000)$ and insomnia $(F=17.431$, $p=.000)$ also increases; there are significant differences between both groups in the variables of nausea $(F=5.635$, $p=.004)$, pain $(F=6.249, p=.017)$ and insomnia $(F=$ $17.431, p=.000)$, although this cannot be said about the perception of vomiting $(F=2.899, p=.099$.

There are no differences in the interaction between both moments of measurement (Day 0-Day of discharge) and groups of nausea $(F=0.013, p=.912)$, vomiting $(F=0.331$, $p=.569)$ and insomnia $(F=1.151, p=.291)$, although there are differences in the perception of pain $(F=4.212, p=.048)$.

\section{DISCUSSION}

With this study, we aim to determine the emotional impact on the patient candidate for HPT and the repercussions of a psycho-oncologic program (before the transplant) on the perception of time, as well as its influence on the mood, on the level of activity, and on the perception of the physical symptomatology of the patients during their required stay in isolation.

There are many authors who state the need of a psychooncologic intervention to help patients who suffer oncohaematologic diseases cope with new situations, that are not only stressful because they are unknown, but also, and most importantly, because they put the patient's health and life at risk, such as the haematopoietic progenitor cell transplant ( De Linares et al., 2007; Arranz \& Coca, 2003; Romero, Ibánez \& Monsalve, 2000) $)^{(39,43,44)}$.

In the intervention group the levels of anxiety and depression are diminishes in the more effective and efficient way, before and after the transplant. Even more, their anxiety and depression levels when facing the process can be considered more adaptative. On the contrary, patients that did not receive the psychological program show the decrease in the anxiety and depression levels in a more gradual way than the intervention group ones. This could be ought to the normal adaptation to ant process considered negative and for to the start up of more efficient conducts of confrontation in environments known by patients (Pulgar, Garrido, Alcalá \& Reyes del Paso, 2012; Moyer, Goldenberg, Hall, KnappOliver. Sohl, Sarma \& Schneide, 2012) ${ }^{(45,46)}$.

According to the results obtained in this work, the anxiety and depression answers do not keep stable, unlike what Syrjala et al. (1993) (47). In their study, the responses keep dug in along the treatment and the follow-up. They conclude that anxiety and depression improve throughout the process in the intervention group and in the control group either. In this way, the intervention group from presenting clinical valued in anxiety and depression, in the diagnosis, to normal values after the intervention, on the admission to undergo the transplant, keeping stable during the follow-up.

The presented data confirms that patients who are going to undergo a haematopoietic progenitor cell transplant present, in general, a more adaptive perception during their stay in isolation if they receive a psycho-oncologic program in preparation for the transplant before the beginning of the treatment whose main objective is to favour the adaptation to the transplant process, decreasing, where possible, its negative effects. In other words, the psycho-oncologic intervention considerably improves the perception of discomfort in the patient which is related to the secondary effects of the treatment of the transplant, such as the lengthening of time passing due to a lack of activity, the worsening of the mood, and an increase in the perception of physical symptoms

The patients in the intervention group present a more adaptive perception of the passage of time than the patients in the control group, who perceive that time passes much more slowly. As Bayés et al.(2003) ${ }^{(28)}$ confirm, patients present a perception of lengthening of time due to the situation of isolation itself, which is perceived as unpleasant, whereas in the case of shortening, the perception is influenced by the motivation in the realisation of activities that require a certain attention level. Because of this, we find the same results referring to the perception of the activity, in such a way that patients in the intervention group engage more in activities during the isolation period than patients in the control group, who perceive a greater level of boredom. As well as Fraisse $(1984)^{(26)}$, we believe that our data shows that the perception of time seems to decrease when patients carry out interesting tasks, in such a way that the more attention paid to the task, the shorter the time is perceived; when a person finds himself totally absorbed in the task they are carrying out, time seems to shorten and hours pass without hardly being noticed.

These shortening of time-passing factors, due to carrying out interesting tasks, may influence the fact that patients in the intervention group present a more positive perception of their mood during isolation than the patients of the control group, who present a worse mood.

With respect to the perception of the secondary effects, the patients of the intervention group do not present, overall, a minor perception of the physical symptomatology during the period in isolation than the patients of the control group. 
According to our results, the perception of the physical symptomatology increases, in general, with the amount of time spent in isolation, with all patients showing a higher level of nausea, vomiting, pain and insomnia. These results contradict, to a certain extent, the data of the study carried out by Bayés et al. (2003) ${ }^{(27)}$ in which they analyse this relationship in 371 patients in a terminal situation, observing that in those patients who felt "bad" or "very bad", time was "long" or "very long", whereas patients who felt "good" or "very good" perceived a reduction in the perception of time. In the study here presented, the results confirm that the perception of time passing is not only related to physical symptomatology, but to the promotion of the activity, the improvement of mood, and a minor attention to physical symptoms. Therefore, we can conclude that patients who undergo HPT and follow a psycho-oncologic intervention, manage to reduce the perception of discomfort, as reflected in the perception of the passage of time. In the same way, our results do not support the suggestion by Holland et al. $(1977)^{(11)}$ who maintain that patients in general adapt to the protected environment and keep an emotional stability, their psychological function being closely associated to their physical state. Our data show that the best adaptation happens due to the previous psycho-oncologic intervention, regardless of the secondary effects perceived by the patient.

If we take as a reference the model of competence or potentiation, that considers that people have capacities or resources to cope in adverse situations, we can conclude that the patients possess abilities and self-resources to confront a treatment process such as HPT. It is the situation of uncertainty, caused by fear, incapacity, and a lack of control that causes the perception of their self-resources to remain latent during the isolation period. That is why, we should help patients, and those around them, perceive a greater control of the situation and find their own coping resources before undergoing a transplant in order to be able to face the process in a more adaptive way. The encouragement of self-resources significantly improves the perception of time passing because they increase the activity during the isolation, and at the same time it relates to an improvement of the mood helping the patients continue with the process in a more adaptive way, despite suffering the secondary effects caused by the treatment (immunosuppression, vomiting, mucositis, fever, etc.).

We can conclude that a specialised psycho-oncologic intervention, adapted to the process of the patients who have to undergo a transplant, is of great help in the adaptation to such a process. The training in cognitive-behavioural techniques, in organisation of their time through their own resources and keeping them constantly informed about the whole process, helps prevent and treat the possible emotional reactions during an isolation process such as the one required for the haematopoietic progenitor cell transplant.

These results demonstrate the effectiveness of psychooncologic preparation programs before a transplant, and at the same time they open new future research fields. One of these fields could be related to the study of the individual differences, that is, it would try to test to what extent some included modules could be more useful for people with determined personality traits, or who present different emotional reactions. Another proposal for future research could be to examine the benefits that the inclusion of additional modules could imply for the patient and family's wellbeing, such as for example, the work done with the family, the sense of humour, or the physical exercise during the isolation period.

\section{REFERENCES}

Arranz, P., \& Coca, C. (2003). Intervención psicológica en un servicio de Hematología [Psychological intervention in a hematology department]. In E. Remor, P. Arranz, \& C. Ulla, El psicólogo en el ámbito hospitalario [Psychologist in the hospital setting] (pp. 641-678). Bilbao: Desclée De Brouwer.

Ascencio, L. (2011). Evaluación psicológica para protocolo de trasplante de células hematopoyéticas en adolescentes [Psychological evaluation for protocol of transplant of cells hematopoyéticas]. Psicología y Salud, 21, 253-263.

Ball, K.K., Beard, B.L., Roenker, D.L., Miller, R.L., \& Griggs, D.S. (1988). Age and visual search: Expanding the useful field view. Journal of the Optical Society of America, 5, 2210-2219. http://dx.doi.org/10.1364/ JOSAA.5.002210

Bárez, M., Blasco, T., \& Fernández J. (2003). La inducción de sensaciones de control como elemento fundamental de la eficacia de las terapias psicológicas en pacientes de cáncer [The feelings of control induced by psychological interventions in cáncer patients: are they the main key to explain the efficacy observed?]. Anales de Psicología, 19, 235-246.

Bayés, R. (2000). Los tiempos de espera en medicina [Waiting times in medicine]. Medicina Clínica, 114, 464-467.

Bayés, R. (2001). Psicología del sufrimiento y de la muerte [Psychology of suffering and death]. Barcelona: Martínez Roca.

Bayés, R. (2002). Tiempo y enfermedad [Time and illness] Estudios de Psicologia, 23(1), 101-110. http://dx.doi.org/10.1174/021093902753535213

Bayés, R., \& Morera, M. (2000). El punto de vista del paciente en la práctica 
clínica hospitalaria [Patient's viewpoint in hospital practice]. Medicina Clínica, 115, 141-144.

Bayés, R., Limonero, J.T., Barreto, P., \& Comas, M.D. (1997). A way to screen for suffering in palliative care. Journal Palliative Care, 13, 22-26.

Bayés, R., Limonero, J.T., Barreto, P., \& Comas, M.D. (1997). A way to screen for suffering in palliative care. Journal Palliative Care, 13, 22-26.

Bayés, R., Limonero, J.T., Barreto, P., \& Comas, M.D. (2001). Protocolo de una investigación multicéntrica sobre aspectos emocionales en enfermos en situación terminal [A research system for emotional needs of terminal patients]. Medicina Paliativa, 8(2), 71-79.

Bjelland, I., Dahl, A. A., Haugh, T. T. \& Neckelmann, D. (2002). The validity of the Hospital Anxiety and Depression Scale. An updated literature review. Journal of Psychosomatic Research, 52, 69-77.

Campion, E.W. (2001). A symptom of discontent. New England Journal Medicine, 344, 223-225. http://dx.doi.org/10.1056/NEJM200101183440311

Carreras, E., Brunet, S., Ortega, J.J., Monserray, E., Sierra. J., \& Urbano-Ispizua, A. (2006). Manual de Trasplante Hemopoyético [Hemopoietic Transplant Manual]. Barcelona: Antares

Cruzado, J.A., \& Olivares, M.E. (2000). Intervención psicológica en pacientes de cáncer [Psychological intervention in cancer patients]. In J.M. Buceta, A.M. Bueno, \& B. Bas, Tratamiento psicológico de hábitos y enfermedades [Psychological treatment of habits and diseases] (pp. 341-402). Madrid: Pirámide

De Linares, S., Moratalla, A., Romero, A., De Pablos, J.M., López, P., Navarro, P., Almagro, M., \& Jurado, M. (2007). Información, ansiedad y depresión en pacientes sometidos a trasplante de progenitores hematopoyéticos (TPH) en un estudio de intervención psicológica [Information, anxiety and depression in patients who have to undergo a haematopoietic progenitor cell transplant in psuchological intervention study]. Psicooncología, 4(1), 97-109.

Dempster, M.D., McCorry, N.K., Brennan, E., Donnelly, M., Murray, L.J., \& Johnston, B.T. (2011). Do changes in illness perceptions predict changes in psychological distress among oesophageal cancer survivors? Journal of Health Psychology, 16(3), 500-509. http://dx.doi. org/10.1177/1359105310386633

Dobkin, P.L., \& Da Costa, D. (2000). Group psychotherapy for medical patients. Psychology, Health \& Medicine, 5(1), 87-96. http://dx.doi. org/10.1080/135485000106034

Folkman, S., \& Greer, S. (2000). Promoting psychological well-being in the face of serious illness: When theory, research and practice inform each other. Psycho-Oncology, 9, 11-19. http://dx.doi.org/10.1002/(SICI)10991611(200001/02)9:1<11::AID-PON424>3.3.CO;2-Q

Fraisse, P. (1984). Perception and estimation of time. Annual Review of Psychology, 35, 1-36. http://dx.doi.org/10.1146/annurev.psych.35.1.1

Gabriel, B., Bromberg, E., Vandenbovenkamp, J., Walka, P., Kornblith, A.B., \& Luzzatto, P. (2001). Art therapy with adult bone warrow transplant patients in isolation: a pilot estudy. Psycho-Oncology, 10, 114-123. http://dx.doi.org/10.1002/pon.498

Gambara, H., Botella, J., \& Gempp, R. (2002). Tiempo vacío y tiempo lleno. Un meta-análisis sobre los cambios en la percepción del tiempo en la edad [Empty time and full time. A meta-analysis of age-related changes perceiving time]. Estudios de Psicología, 23(1), 87-100. http:// dx.doi.org/10.1174/021093902753535204

Hengeveld, M.W., Houtman, R.B., \& Zwan, F.E. (1988). Psychological aspects of bone marrow transplantation: a retrospective study of longterm survivors. Bone Marrow Transplant, 3, 69-75.

Holland, J., Plumb, M., Yates, J., Harris, S., Tuttolomondo, A., \& Holmes J. (1977). Psychosocial response of patients with acute leukaemia to germfree enviroments. Cancer, 40, 871-879. http://dx.doi.org/10.100/10970142(197708)40:2<871::AID-CNCR2820400241>3.0.CO;2-Y

Hou, W.K., Law, C.C., \& Fu, Y. T. (2010). Does change in positive affect mediate and/or moderate the impact of symtom distress on psychological adjustment after cancer diagnosis? A prospective analysis. Psychology \& Health, 25(4), 417-431. http://dx.doi.org/10.1080/08870440802559375

Juola J. (2001). Efectos del envejecimiento sobre la atención visual [Effects of age on visual attention]. In C. Méndez, D. Ponte, L. Jiménez, \& M.J. Sanpedro, La Atención: un enfoque multidisciplinar [Attention: a multidisciplinary approach] (pp. 313-324). Valencia: Promolibro

Kirchhoff, K. \& Kehl, K. (2007). Recruiting participants in end-of-life research. Journal Hospital Palliative Care, 24, 515-521.

Lesko, L.M. (1989). Bone marrow transplantation. In J. Holland, \& J. Rolland, Handbook of Psychooncology (pp. 163-173). New York: Oxford University Press

Lesko, L.M., Kern, J., \& Hawkins, D.R. (1984). Psychological aspects of patients in germ-free isolation: a review of child, adult and patient management literature. Medicine Pediatric Oncology, 12, 43-49. http:// dx.doi.org/10.1002/mpo.2950120111

Mosher, C.E., Redd, W.H., Rini, C.M., Burkhalter, J.E., \& DuHamel, K.N. (2009). Physical, psychological, and social sequelae following hematopoitetic stem cell transplantation: a review of the literature. Psycho-Oncology, 18, 113-127. http://dx.doi.org/10.1002/pon.1399

Moyer, A., Goldenberg, M., Hall, M. A., Knapp-Oliver, S. K., Sohl, S. J. \& Sarma, E. A. (2012). Schneider S. Mediators of Change in Psychosocial Interventions for Cancer Patients: A Systematic Review. Behavioral Medicine, 38(3), 90-114.

Neuser, J. (1988). Personality and survival time after bone marrow transplantation. Journal Psychosomatic, 32, 451-455. http://dx.doi. org/10.1016/0022-3999(88)990029-3

Novoa, G. M. N., Vargas, G. R. M., Obispo, C. S. A., Petrus, V. M. \& Rivera P. Y. K. (2010). Evaluation of quality of life and psychological welfare in patients with postquirurgical condition and thyroid cancer. International Journal of Psychology and Psychological Therapy, 10(2), 315-329.

Pinquart, M., \& Fröhlich, C. (2009). Psychosocial resources and subjective 
well-being of cancer patients. Psychology \& Health, 24(4), 407-421. http://dx.doi.org/10.1080/08870440701717009

Pulgar, Á, Garrido, S, Alcalá, A., Reyes del Paso, G. A. (2012). Psychosocial Predictors of Immune Response Following. Bone Marrow Transplantation. Behavioral Medicine, 38 (1), 12-18.

Romero, R., Ibáñez, E., \& Monsalve, V. (2000). La terapia psicológica adyuvante en enfermas con cáncer de mama: un estudio preliminar [Adjuvant psychological therapy in patients with breast cancer: a preliminary study]. In F. Gil, Manual de Psico-Oncología [Manual of Psycho-Oncology] (pp. 15-37). Madrid: Nova Sodonia Oncología.

Ruiz, G.J. (2009). Fundamentos de hematología [Fundamentals of hematology]. Madrid: Auto-Editor.

Salthouse, T.A. (1991). Theoretical perspectives on cognitive aging. New Jersey: Erlbaum: Hillsdale.

Sans-Sabrafen, J., Berres, R. C \& Vives, J. C. Hematologia Clínica. (2006) Barcelona: Elsevier.

Schroevers, M. J., Kraaij, V. \& Garnefski, N. (2011). Cancer patients' experience of positive and negative changes due to the illness: relationships with psychological well-being, coping, and goal reengagement. Psycho-Oncology, 20, 165-172.

Schroots, J.J.F., \& Birren, J.E. (1990). Concepts of time and aging in science. In J.E. Birrren, \& K.W. Schaie, Handbook of the psychology of aging (pp. 45-64). San Diego: Academic Press

Syrjala, K. L., Chapko, M. K., Vitaliano, P. P., Cummings, C. \& Sullivan, K. (1993). Recovery after allogeneic marrow transplantation: prospective study of predictors of long-term physical and psychosocial functioning. Bone Marrow Transplant; 11, 319-226

Trask, P.C, Paterson, A., Riba, M., Brine, B., Griffi, K. y Parker, P. (2002). Assessment of psychological distress in prospective bone marrow transplant patients. Bone Marrow Transplant, 29, 917-925.

Watson, M., St. James-Roberts, I. y Ashley, S. (2006). Factors associated with emotional and behavioural problems among school age children of breast cancer patients. British Journal of Cancer, 94(1), 43-50.

Watson, M., Haviland, J.S., Greer, S., Davidson, J., \& Bliss, J.M. (1999). Influence of psychological esponse on survival in breast cancer: a population- case cohort study. Lancet, 354, 1331-1336. http://dx.doi. org/10.1016/S0140-6736(98)11392-2

Wettergren, L., Sprangers, M., Björkholm, M., \& Langins-Eklöf, A. (2008). Quality of life before and one year following stem cell transplantation using and individualized and a stardarized instrument. Psycho-Oncology, 17, 338-346. http://dx.doi.org/10.1002/pon.1240

Zigmond, A.S., \& Snaith, R.P. (1983). The hospital anxiety and depression scale. Acta Psychiatrica Scandinavica, 67, 361-370. http://dx.doi. org/10.1111/j.1600-0447.1983.tb09716.x 